\title{
HONORARIUM
}

\section{On the award of TMS Honorary Membership, 17 November 2010 to Dr James Riding}

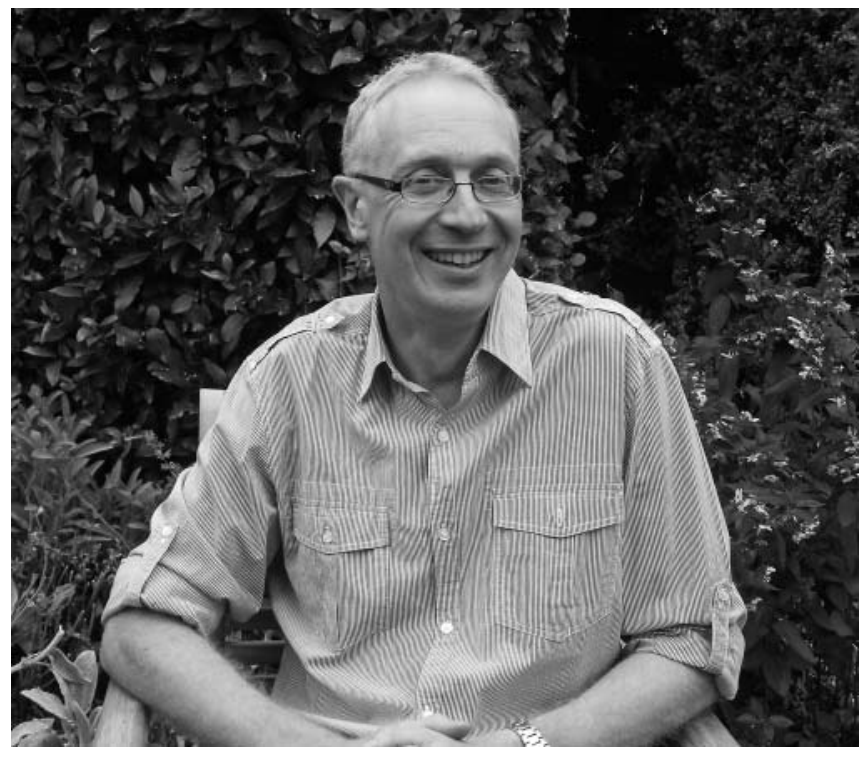

James (Jim) Riding was born in Sheffield in the Yorkshire Pennines on 6 October 1957, growing up in the Penistone neighbourhood. He attended primary school in Denby Dale (famous for its giant meat pie baked for special occasions and events) and from there went to Penistone Grammar School where he studied A Level Geology. From early on Jim was a keen amateur geologist and, whilst in the sixth form, he attended a WEA evening class on geology, as well as participating in many local geological expeditions. It was during these expeditions around Langsett (famous for the Upper Carboniferous Langsettian stratotype) that Jim's passion for palaeontology developed while collecting Carboniferous macrofossils (he also discovered the variety of beers at the local pubs with his school friend, Andrew Bloodworth). Following the Geology call, Jim enrolled for a BSc in Geology at Leicester in 1976 and then pursued an MSc in Micropalaeontology at the University of Sheffield in 1980. It was in the autumn of 1980 that Jim joined the British Geological Survey (BGS) at Leeds as a palynologist. During his early years at the BGS, Jim completed a University of Sheffield PhD on Jurassic dinoflagellate cyst floras of northern and eastern England (1986). In 1987 he received the President's Award of the Geological Society of London. His most recent academic award was in 2003, with a DSc from the University of Leicester for Mesozoic/Cenozoic palynology. Since 1984 Jim has been located at the BGS office at Keyworth near Nottingham. He has participated in summer field seasons with the British Antarctic Survey in 1989 and 2006, and undertook a secondment to Geoscience Australia (1999-2000) to work on the taxonomy of Australian Jurassic dinoflagellate cysts with Robin Helby and Clinton Foster.

If you ask him what sort of palynologist he is, Jim would answer that he considers himself as a palaeopalynologist, mostly concerned with stratigraphy and sedimentary basin history for the Phanerozoic period, but is also very interested in palynology of Europe, Australasia, Antarctica, West Africa, the Americas, Russia and the Middle East, palynomorph provincialism, forensic palynology, palaeoenvironmental palynology, palynomorph preparation techniques and the morphology, systematics and taxonomy of dinoflagellate cysts. When looking at his very long list of publications (over 150 articles in journals and books), one can see the enormous contribution he has made to knowledge of Jurassic dinoflagellate cysts from England and elsewhere. Undoubtedly, if you need to know anything about the Jurassic palynoflora of Europe, Jim is your man. During his 30 year-long career, Jim has been prolific in the description of new palynomorph taxa, with 84 new species and 19 new genera of Jurassic and Cretaceous dinoflagellate cysts, one trilete spore from the Lower and Middle Jurassic and a few acritarch species and a genus. His average publication rate of five papers per year (a 'poor year' would yield one publication, a 'good' one 14) is one that is inspiring. In addition to this impressive research output, he was one of the co-organizers of the successful AASP-TMS-NAMS joint meeting in September 2002 in London, together with James Powell, Chris Denison, Tom Dignes, Alan Lord, Susan Matthews and Rachel Preece. But, more importantly, I was told that Jim has one unconditional lifelong passion besides palynomorphs: Sheffield Wednesday Football Club. No need to say more. Although Jim's primary interest involves Jurassic palynomorphs, he does not hesitate to dabble with more recent material, looking at the palynoflora of the Devensian (Riding et al., 2003) or Pre-Roman Iron Age (Denford \& Riding, 1992), and even footwear - yes, wellington boots - to study how mud stuck on shoes can be used for forensic palynology (Riding et al., 2007). Another hobby of Jim's is to find the best recipe to prepare palynomorphs (Riding \& Kyffin-Hughes, 2010).

Although Jim's job is not a teaching position, he has been involved in the Urbino Summer School (organized by Henk Brinkhuis, University of Utrecht), teaching in 2004, 2006 and 2009 on Triassic, Jurassic and Lower Cretaceous dinoflagellate cysts, as well as supervising and co-supervising MSc and $\mathrm{PhD}$ students. One can say that Jim can certainly multi-task.

From early on, Jim has actively participated in the life of different micropalaeontological societies. He was the Secretary of The Micropalaeontological Society (1988-1995) and its Treasurer (1995-2003). Meanwhile, he was the President of the American Association of Stratigraphic Palynologists (20012004; Director-at-Large in 1999) and Vice-President of the International Federation of Palynological Societies (2003present day). Currently, Jim is the Managing Editor for Palynology (since 2004), a job that all editors know is a very demanding one, sometimes frustrating but most of the time very rewarding. Recognition of Jim's dedication to palynology and his scientific achievements is well deserved.

The Micropalaeontological Society is pleased to grant Honorary Membership to Dr James Riding. 


\section{REFERENCES}

Denford, G.T. \& Riding, J.B. 1992. A note on the palynological analysis of a Late Pre-Roman Iron age shale vessel from Harpenden. Bedfordshire Archaeology, 19: 95-97.

Riding, J.B., Rose, J. \& Booth, S.J. 2003. Allochthonous and indigenous palynomorphs from the Devensian of the Warham Borehole, Stiffkey, north Norfolk, England; evidence for sediment provenance. Proceedings of the Yorkshire Geological Society, 54: 223-235.

Riding, J.B., Rawlins, B.G. \& Coley, K.H. 2007. Changes in soil pollen assemblages on footwear worn at different sites. Palynology, 31: $135-151$.
Riding, J.B. \& Kyffin-Hughes, J.E. 2010. The use of pre-treatments in palynological processing. Review of Palaeobotany and Palynology, 159: $281-290$.

Fabienne Marret

Department of Geography, University of Liverpool, Roxby Building, Liverpool L69 7ZT, UK (e-mail:f.marret@liv.ac.uk) 